\title{
Lactic dehydrogenase activity in the aqueous humour of eyes containing malignant melanomas
}

\author{
R. PORTER* AND A. W. SKILLEN†
}

From the University Departments of Ophthalmology* and Clinical Biochemistry, $\dagger$ Royal Victoria Infirmary, Newcastle-upon-Tyne

It is known that malignant cells contain a higher concentration of the enzyme lactic dehydrogenase $(\mathrm{LDH})$ and its associated isoenzymes than normal tissues (Latner, Turner, and Way, 1966), and that as a result the body fluids which surround malignant tissues contain an increased concentration of LDH (Wroblewski, 1957). More recently Dias, Senthe Shanmuganathan, and Rajaratnam (197I) have reported increased LDH activity in the aqueous humour of eyes containing retinoblastomas, and have suggested that this may be a useful diagnostic test for malignant intraocular tumours.

The purpose of this paper is to estimate whether a similar increase in LDH activity occurs in the aqueous humour of eyes containing the more commonly occurring malignant melanomas.

\section{Method}

Aqueous humour was aspirated from the anterior chamber in 27 patients using a 20-gauge needle introduced at the limbus. The specimens were stored at $5^{\circ} \mathrm{C}$. before analysis. The patients comprised seven cases of intraocular malignant melanoma and twenty control cases with nonmalignant conditions, of various ages from $I$ to 73 years. In the controls the aqueous was aspirated immediately before surgery involving the opening of the anterior chamber and the removal of the lens.

LDH activity was estimated at $35^{\circ} \mathrm{C}$. with a LKB Reaction Rate Analyser. Both the pyruvate to lactate and the reverse reaction were used. The former involved diluting a 50- $\mu$ l. sample with $1 \cdot 4$ $\mathrm{ml}$. $\mathrm{O} \cdot \mathrm{IM}$ phosphate buffer containing $12 \mathrm{mg}$. reduced nicotinamide adenine dinucleotide (NADH) per $100 \mathrm{ml}$. The reaction was initiated with $50 \mathrm{ml}$. $0.01 \mathrm{M}$ pyruvate and the resultant change in absorbance at $340 \mathrm{~nm}$ was recorded for $\mathrm{I}$ minute. The reverse reaction involved the dilution of the 50- $\mu$ l. sample with $0.1 \mathrm{MHCl}, \mathrm{pH} 9 \cdot 5$, containing $0 . \mathrm{I} \mathrm{M}$ lithium lactate. The reaction was initiated with $50 \mu \mathrm{l}$. nicotinamide adenine dinucleotide (NAD) (10 $\mathrm{mg} . / \mathrm{ml}$. ).

Since Dias and others (197I) had used the lactate to pyruvate method this was initially used in two of the melanoma cases, but the level of activity estimated was found to be low. Test estimations of LDH in sera, using pyruvate as the substrate, gave levels approximately twice that found when lactate was the substrate. It was therefore decided to carry out all subsequent estimations using pyruvate as the substrate. 


\section{Results}

These are set out in Tables I and II.

Table I LDH activity in twenty control cases

\begin{tabular}{|c|c|c|}
\hline Diagnosis & $\begin{array}{l}\text { No. of } \\
\text { patients }\end{array}$ & $\begin{array}{l}\text { Range of } L D H \\
\text { (units/litre) }\end{array}$ \\
\hline Congenital cataract & 4 & 5 to 20 \\
\hline Painful blind eye & 2 & 7 and 22 \\
\hline Cataract & 14 & 5 to 25 \\
\hline
\end{tabular}

* The first two cases were estimated using lactate as the substrate. In the other five pyruvate was used as the substrate. In Cases 1,3 , and 5 large choroidal melanomas almost filled the eye. In Cases 4,7 , and in particular Case 6 the tumours were much smaller.
Table II $L D H$ activity in cases of malignant spindle cell melanoma*

\begin{tabular}{|c|c|c|}
\hline Case no. & Site of tumour & $\begin{array}{l}\text { Range of } L D H \\
\text { (units/litre) }\end{array}$ \\
\hline I & Choroid & I I \\
\hline 2 & Iris & 5 \\
\hline 3 & Choroid & 30 \\
\hline 4 & Ciliary body & 18 \\
\hline 5 & Choroid & 30 \\
\hline 6 & Choroid & II \\
\hline 7 & Ciliary body & 9 \\
\hline
\end{tabular}

\section{Discussion}

In this series of patients the LDH activity in the aqueous humour from eyes containing malignant melanomas was not significantly higher than that found in a control group. Two patients with large melanomas almost filling the eyes had the highest levels of LDH activity recorded, but the overall result does not provide a basis for a reliable diagnostic test for intraocular melanoma.

These levels are much lower than those recorded by Dias and others (197I) and for thiso the well-recognized inaccuracies of the calorimetric techniques (Amador and Wacker, I965) may be partly responsible, but it is also possible that some nonenzymatic constituent may have been the cause. As well as this the four retinoblastomas described were clearly large retrolental tumours and retinoblastomas are generally more friable and are not separated by the retina from the vitreous, thus allowing $\mathrm{LDH}$ greater freedom to diffuse into the vitreous and aqueous.

\section{Summary}

The LDH activity in the aqueous humour of seven eyes containing malignant melanomas was estimated. The level was not found to be significantly raised above that found in twenty control cases with nonmalignant conditions.

We wish to thank Mr. A. L. Crombie, Mr. J. M. L. Howat, Mr. N. Manson, Mr. J. Richardson, and Mr. I. R. Robertson for their cooperation, and Prof. A. L. Latner for his helpful advice.

\section{References}

AMAdOR, E., and WAGKer, w. E. c. (1965) "Methods of Biochemical Analysis", 13, 282. Wiley, New York

Dias, P. L. R., Senthe Shanmuganathan, s., and rajaratnam, m. (I97I) Brit. F. Ophthal., 55, izo LATNER, A. L., TURNER, D. M., and WAY, S. A. (1966) Lancet, 2, 814

WROBLEWSKI, F. (1957) Amer. F. med. Sci., 234, 301 